(2) Open Access Full Text Article

\title{
Assessment of the effects of levosimendan and thymoquinone on lung injury after myocardial ischemia reperfusion in rats
}

This article was published in the following Dove Press journal:

Drug Design, Development and Therapy

\author{
Șaban Cem Sezen' \\ Aysegul Kucuk ${ }^{2}$ \\ Abdullah Özer ${ }^{3}$ \\ Yiğit Kılıç4 \\ Barıș Mardin 3 \\ Metin Alkan ${ }^{5}$ \\ Fatmanur Duruk Erkent ${ }^{5}$ \\ Mustafa Arslan 5 \\ Yusuf Ünal ${ }^{5}$ \\ Gürsel Levent Oktar ${ }^{3}$ \\ Murat Tosun ${ }^{6}$ \\ 'Department of Histology and \\ Embryology, Kirikkale University \\ Medical Faculty, Kirikkale, Turkey; \\ ${ }^{2}$ Department of Physiology, \\ Dumlupinar University Medical \\ Faculty, Kutahya, Turkey; ${ }^{3}$ Department \\ of Cardiovascular Surgery, Gazi \\ University Medical Faculty, Ankara, \\ Turkey; ${ }^{4}$ Pediatric Cardiovascular \\ Surgery Clinic, Dr Siyami Ersek \\ Cardiovascular and Thoracic Surgery \\ Training and Research Hospital, \\ Istanbul, Turkey; ${ }^{5}$ Department of \\ Anaesthesiology and Reanimation, \\ Gazi University Medical Faculty, \\ Ankara, Turkey; ${ }^{6}$ Department of \\ Histology and Embryology, Afyon \\ Kocatepe University Medical Faculty, \\ Afyonkarahisar, Turkey
}

Correspondence: Mustafa Arslan Department of Anesthesiology and Reanimation, Gazi University Medical Faculty, 065I0 Ankara, Türkiye

$\mathrm{Tel}+903122026739 ;+905334228577$

Fax +90312 2024166

Email marslan36@yahoo.com;

mustarslan@gmail.com
Aim: The aim of this study was to investigate the effects of levosimendan and thymoquinone (TQ) on lung injury after myocardial ischemia/reperfusion (I/R).

Materials and methods: Twenty-four Wistar albino rats were included in the study. The animals were randomly assigned to 1 of 4 experimental groups. In Group C (control group), left anterior descending artery was not occluded or reperfused. Myocardial I/R was induced by ligation of the left anterior descending artery for $30 \mathrm{~min}$, followed by $2 \mathrm{~h}$ of reperfusion in the I/R, I/R-levosimendan ( $24 \mu \mathrm{g} / \mathrm{kg}$ ) (IRL) group, and I/R-thymoquinone $(0.2 \mathrm{~mL} / \mathrm{kg}$ ) (IRTQ) group. Tissue samples taken from the lungs of rats were histochemically stained with H\&E and immunohistochemically stained with $\mathrm{p} 53, \mathrm{Bcl} 2$, Bax, and caspase 3 primer antibodies.

Results: Increased expression of p53 and Bax was observed (4+), especially in the I/R group. In IRTQ and IRL groups, expression was also observed at various locations $(2+, 3+)$. H\&E staining revealed that that the lungs were severely damaged and the walls of the alveoli were too thick, the number of areas examined was increased during the evaluation. Caspase 3 expression was observed to be at an $(1+, 2+)$ intensity that was usually weak and diffuse in multiple areas. $\mathrm{Bcl} 2$ was not found to be expressed in any of the tissues. H\&E staining revealed that that the lungs were severely damaged in the I/R group, with the walls of the channels and alveoli thickened and edematous, and also an intense inflammatory cell migration was observed. Immunohistochemical staining was more prominent in inflammatory areas and structures around the terminal bronchioles.

Conclusion: The findings in our study have shown that administration of levosimendan and TQ during I/R increases expression of caspase 3, p53, and Bax in lung tissue and has a protective effect on lung as distant organ. We suggest that findings of this study be elucidated with further large-scale clinical studies.

Keywords: ischemia reperfusion, levosimendan, thymoquinone, lung, caspase 3, p53

\section{Introduction}

Myocardial ischemia/reperfusion (I/R) injury is a common clinical incident. ${ }^{1-3}$ Despite optimal myocardial reperfusion, morbidity and mortality rates of patients with ischemic cardiomyopathy are still high due to the myocardial reperfusion injury. ${ }^{4-6}$

Reperfusion of the previously ischemic myocardium causes arrhythmia following oxidative stress. This may even be life-threatening and ends with cardiac remodeling and dysfunction. ${ }^{7,8}$ If the blood flow is not restored, this creates a scar tissue, leading to left ventricular dysfunction, and in the end heart failure. ${ }^{9}$

Ischemia activates anaerobic metabolism, reperfusion paradoxically enhances local tissue damage simultaneously with inflammatory response, and this causes distant organ 
damage. ${ }^{10}$ Increased vascular permeability, inflammatory response, and cell apoptosis (eg, $\mathrm{Bax}$ and $\mathrm{Bcl} 2$ ) causes acute lung injury. ${ }^{11,12}$

It is well known that following I/R injury an uncontrolled release of reactive oxygen species, cytokines, and prostaglandins occurs. ${ }^{13}$ A cascade of hyperactivated inflammatory response, increased intracellular $\mathrm{Ca}$, and intracellular Ca-dependent lipid peroxidation damage cells, tissues, and organs. After the first few minutes of reperfusion, free oxygen radicals are produced and aggravate the acute ischemic injury, leading to renal cellular death. ${ }^{14}$ In contrast to activation of destroying factors, several protective mechanisms include glutathione peroxidase, superoxide dismutase activation, and, at cellular level, gene expressions of p-53, Bax, and Bcl 2.

p53 has an important role during apoptotic cell death processes triggered by hypoxia, DNA damage, or improper oncogene signaling. Following p53 activation, transcription of several genes starts. If these transcriptional molecules repair DNA damage, the cell cycle continues; if not, p53-induced apoptosis begins. Proapoptotic genes such as Bax, p53, and PUMA play critical roles in cell apoptosis. ${ }^{15}$ During acute renal I/R injury, renal tubular epithelial cells and vascular endothelial cells are damaged, and subsequently necrosis and apoptosis result in cellular death. ${ }^{16}$ Increased cytokine and receptor (FasL, Fas) expressions, abnormal expressions of apoptotic regulators such as Bcl 2, Bax, and Bcl-xl, and caspase functions are important factors during apoptotic cascade. On the other hand, several studies demonstrated that inhibition of apoptotic cell death by p 53 inhibition can restore the renal injury and ongoing inflammatory process. ${ }^{15,16}$

Levosimendan (L) is a relatively new inotropic and vasodilator agent used in the management of acute and chronic heart failure. ${ }^{17}$ Its positive inotropic effect is mediated by calcium sensitization of contractile proteins, and its vasodilatory and anti-ischemic effects are mediated by the opening of adenosine triphosphate-sensitive potassium channels in vascular smooth muscle cells. ${ }^{17-19}$ The protective effects of $\mathrm{L}$ are not limited to cardiac tissue, but $\mathrm{L}$ also attenuates $\mathrm{I} / \mathrm{R}$ injury in the spinal cord, lung, and renal tissue..$^{20-22}$

Thymoquinone (TQ) is one of the compounds of Nigella sativa (NS). It is the main active ingredient of NS, commonly known as black cumin or black seed, an annual flowering plant native to some areas such the Mediterranean countries. ${ }^{23}$ Since its first extraction in 1963, ${ }^{24}$ TQ has been shown to act as a potent free radical and superoxide scavenger. ${ }^{25,26}$ Some studies have suggested that TQ also attenuates I/R injury in the spinal cord, heart, and renal tissue. ${ }^{27-29}$
Myocardial I/R injury treatment is still at the center of the much current research. Earlier studies on I/R injury have focused on ischemic preconditioning and ischemic postconditioning, ${ }^{4,30}$ and myocardial infarction size has been reported to be limited. ${ }^{31,32}$ However, most of the clinical trials to prevent reperfusion injury have not been satisfactory. ${ }^{33}$ A therapy to prevent the myocardial reperfusion injury has not been found yet. ${ }^{5}$

Among the distant organs, distant organ injury after myocardial I/R injury is defined best in the lung. ${ }^{34}$ Many distant organs such as kidney, intestines, and pancreas may also be damaged by free oxygen radicals released from the ischemic myocardium. ${ }^{35}$ If an effective therapy to prevent the myocardial and distant organ reperfusion injury could be found, we can reduce the mortality and morbidity rates caused by $\mathrm{I} / \mathrm{R}$ injury.

Therefore, the present study was designed to investigate the protective effects of intraperitoneally administered $\mathrm{L}$ and TQ on lungs against I/R injury before and after occlusion of the left anterior descending (LAD) coronary artery.

\section{Materials and methods}

\section{Animals and experimental protocol}

This study was carried out in the GUDAM Laboratory of Gazi University with the approval of the Experimental Animals Ethics Committee of Gazi University (09/05/2017E.67709 GÜET-16.013). All procedures were carried out in accordance with the standards in the Guide for the Care and Use of Laboratory Animals. In this study, 12 weeks old 24 male Wistar Albino rats weighing between 250 and $300 \mathrm{~g}$, raised under the same environmental conditions, were used. Animals were housed in standard cages in a pathogen free environment at least 1 week prior to surgery. During this time, they had free access to food (until $2 \mathrm{~h}$ before the anesthetic procedure) and water. The animals were kept under a constant $12 \mathrm{~h}$ dark/light cycle and they were randomly separated into 4 groups, each containing 6 rats. The rats were anesthetized with an intraperitoneal (IP) injection of 100 mg/kg of ketamine (Ketalar; Parke-Davis; Pfizer, Inc., New York, NY, USA). The trachea was cannulated for artificial respiration. The chest was shaved, and each animal was fixed in a supine position on the operating table. Left thoracotomy was used to open the chest. The fourth and fifth ribs were sectioned approximately $2 \mathrm{~mm}$ to the left of the sternum. Positive pressure artificial respiration was started immediately with room air, using a volume of $1.5 \mathrm{~mL} / 100 \mathrm{~g}$ body weight at a rate of $60 \mathrm{strokes} / \mathrm{min}$. Sodium heparin $(500 \mathrm{IU} / \mathrm{kg}$ ) was administered through the 
peripheral vein in the tail for the maintenance of reperfusion after occlusion.

The pericardium was incised. With gentle pressure on the right side of the rib cage, the heart was exteriorized. A 8/0 silk suture attached to a $10 \mathrm{~mm}$ micropoint reverse-cutting needle was quickly placed under the left main coronary artery. Then, the heart was carefully replaced in the chest, and then 20 min was given for the animal to recover.

Anesthesia was maintained by repetitive injections of $20 \mathrm{mg} / \mathrm{kg}$ ketamine if a positive reaction to surgical stress or intermittent tail pinch could be observed.

There were 4 experimental groups: Group C (control), Group I/R, Group IRTQ (I/R-thymoquinone), and Group IRL (I/R-levosimendan). After left thoracotomy, the IRL group received IP levosimendan (Simdax $2.5 \mu \mathrm{g} / \mathrm{mL}$; Orion Pharma, Espoor, Finland) $24 \mu \mathrm{g} / \mathrm{kg}$ diluted in $10 \mathrm{~mL}$ of $0.5 \%$ dextrose administered intraperitoneally $30 \mathrm{~min}$ before ligating the LAD artery. The IRTQ group underwent left thoracotomy and received IP NS (TQ 1G; Sigma Aldrich ${ }^{\circledR}$, St Louis, MO, USA) $0.2 \mathrm{~mL} / \mathrm{kg}$ administered IP $30 \mathrm{~min}$ before ligating the LAD artery. TQ was dissolved in dimethyl sulfoxide (DMSO), followed by the addition of $0.9 \%$ saline solution (1:1) on a daily basis and IP administered at a dose of $25 \mathrm{mg} / \mathrm{kg} 30 \mathrm{~min}$ prior to ligation in the drug-treated groups (suspension contained TQ equivalent to $125 \mathrm{mg}$ TQ per $\mathrm{mL}$ ). A small plastic snare was threaded through the ligature and placed in contact with the heart. The artery was then occluded by applying tension to the ligature (30 $\mathrm{min}$ ), and reperfusion was achieved by releasing the tension (120 $\mathrm{min}$ ). However, after the above procedure, the coronary artery was not occluded or reperfused in the control rats. At the end of reperfusion period, histopathological evaluation of lung tissue specimen was performed. Rats were decapitated at the end of experiment.

\section{Immunohistochemical evaluation}

The lung tissue samples taken from rats were histologically processed and embedded in paraffin. Five micro slides were taken from these blocks and mounted on poly-L-lysine coated slides and immunohistochemically stained with p53, Bcl 2, Bax, and caspase 3 primary antibodies. When the tissues immunohistochemically stained, first the slides deparaffinized and rehydrated. Then, for antigen retrieval, the slides were boiled in citrate buffer using a microwave oven and tissue endogenous peroxidase activity neutralized by $0,3 \mathrm{H}_{2} \mathrm{O}_{2}+$ methanol solution. After primary antibodies were put onto slides, these samples were incubated at $+4^{\circ} \mathrm{C}$ overnight. Then, the slides were washed and stained with horseradish peroxidase (HRP) secondary antibody kit and colored with
AEC chromogen and counterstained with Mayers hematoxylin. Finally, the slides were mounted with a water-based mounting medium and evaluated under light microscope.

Under light microscope, immunopositive cell distribution and immunopositivity degree were evaluated by double-blind testing.

\section{Statistical analysis}

The Statistical Package for the Social Sciences (IBM Corporation, Armonk, NY, USA) 20.0 program was used for the statistical analysis. The Bonferroni-adjusted test was used if the results of the one-way analysis of variance were significant to determine which groups differed from the others. The results were expressed as mean \pm standard deviation (mean $\pm \mathrm{SD}$ ). Statistical significance was set at a $p$-value of $<0.05$.

\section{Results}

Myocardial ischemia resulted in ventricular arrhythmias, which commenced 4-15 min after occlusion and occurred as ventricular tachycardia. The number of animals, in which operations were successful was 6, 6, and 6 in the control, L-, and TQ-treated subgroups, respectively. One animal in the control subgroup died as a result of irreversible ventricular fibrillation during the ischemia period. TQ and $\mathrm{L}$ reduced the incidence of cardiac arrhythmias.

Upon microscopic examination, increased expression of p53 and Bax was observed (4+), especially in the I/R group. In IRTQ and IRL groups, expression was also observed at various locations $(2+, 3+)$. During the evaluation, the number of areas examined was increased because the lungs were extremely collapsed and the walls of the alveoli were too thick. P53 gene expression was significantly increased in all groups compared to the control group ( $p<0.0001$, all). TQ and $\mathrm{L}$ administration significantly decreased $\mathrm{p} 53$ gene expression compared to I/R group ( $p<0.0001, p=0.011$, respectively) (Table 1). Bax gene expression was found to be significantly higher in all groups than in the control group $(p<0.0001$, all). L administration significantly reduced Bax gene expression compared to the I/R group ( $p=0.023$ ) (Table 1). Caspase 3 expression was observed to be at a $(1+, 2+)$ intensity, usually weak, and diffuse in multiple areas. Caspase 3 gene expression was found to be significantly higher in all groups compared to the control group ( $p<0.0001$, all). TQ and L administration significantly decreased Caspase 3 gene expression compared to the $\mathrm{I} / \mathrm{R}$ group $(p<0.0001$, $p<0.0001$, respectively) (Table 1 ). $\mathrm{Bcl} 2$ was not found to be expressed in any of the tissues. In H\&E staining, it was 
Table I Immunohistochemical findings in the lung tissue (mean $\pm \mathrm{SE}$ )

\begin{tabular}{|c|c|c|c|c|c|}
\hline $\begin{array}{l}\text { Apoptosis } \\
\text { mediators }\end{array}$ & $\begin{array}{l}\text { Group C } \\
(n=6)\end{array}$ & $\begin{array}{l}\text { Group I/R } \\
(n=6)\end{array}$ & $\begin{array}{l}\text { Group IRTQ } \\
(n=6)\end{array}$ & $\begin{array}{l}\text { Group IRL } \\
(\mathrm{n}=6)\end{array}$ & $P$-value* \\
\hline p53 & $0.00 \pm 0.00$ & $16.75 \pm 1.13^{* *}$ & $9.13 \pm 1.07 * *, * * *$ & $12.63 \pm 0.75 * *, * * *$ & $<0.0001$ \\
\hline Caspase 3 & $0.88 \pm 0.35$ & $22.63 \pm 1.05 * *$ & $\mid 5.63 \pm 1.29 * *, * * *$ & $16.00 \pm 0.59 * *, * * *$ & $<0.0001$ \\
\hline $\mathrm{Bcl} 2$ & $0.00 \pm 0.00$ & $0.00 \pm 0.00$ & $0.00 \pm 0.00$ & $0.00 \pm 0.00$ & - \\
\hline Bax & $1.25 \pm 0.4 \mathrm{I}$ & $15.25 \pm 0.96 * *$ & $\left.|3.50 \pm| .2\right|^{* *}$ & $11.00 \pm 1.13^{* *, * * *}$ & $<0.0001$ \\
\hline
\end{tabular}

Note: *p: statistical significance was set at a $p$-value $<0.05$ for Kruskal-Wallis test, ** $p<0.05$ : when compared with Group C, *** $p<0.05$ : when compared with Group IR. Abbreviations: C, control; I/R, ischemia/reperfusion; IRL, IR-levosimendan; IRTQ, IR-thymoquinone; SE, standard error.

observed that the lungs were severely damaged in the I/R group, the walls of the channels and alveoli were thickened and edematous, and all of them were filled with blood and fluid; also, there was intense inflammatory cell migration. Immunohistochemical staining was more prominent in inflammatory areas and structures around the terminal bronchioles (Figure 1).

\section{Discussion}

In this study, immunohistochemical and histochemical changes as a result of $\mathrm{L}$ and TQ pretreatment against distant organ (lung) I/R injury were demonstrated.

$\mathrm{L}$ treatment was reported to protect the myocardium, ${ }^{36}$ lungs, ${ }^{21}$ and spinal cord.$^{20} \mathrm{~L}$ shows its protective effect via 2 different ways. First, it sensitizes troponin $\mathrm{C}$ to calcium so during systole without any high energy consumption increased effect of $\mathrm{Ca}$ is observed. Second, as overload of calcium is a trigger factor for oxidative stress, by increasing energy consumption and myocyte dysfunction, L decreases $\mathrm{Ca}$ levels during diastole and results in reduced sensitivity without any calcium overload. In addition, by opening ATP-dependent potassium $(\mathrm{K})$ channels in myocytes and vascular smooth muscle cells vasodilatation is induced. Thus, this contributes to vasodilatation and probably antiischemic effects. ${ }^{37-39}$ In previous studies, L was proven to show protective effects against oxidative injury in animal models via interference with apoptotic signaling and cell survival activation. ${ }^{40,41}$

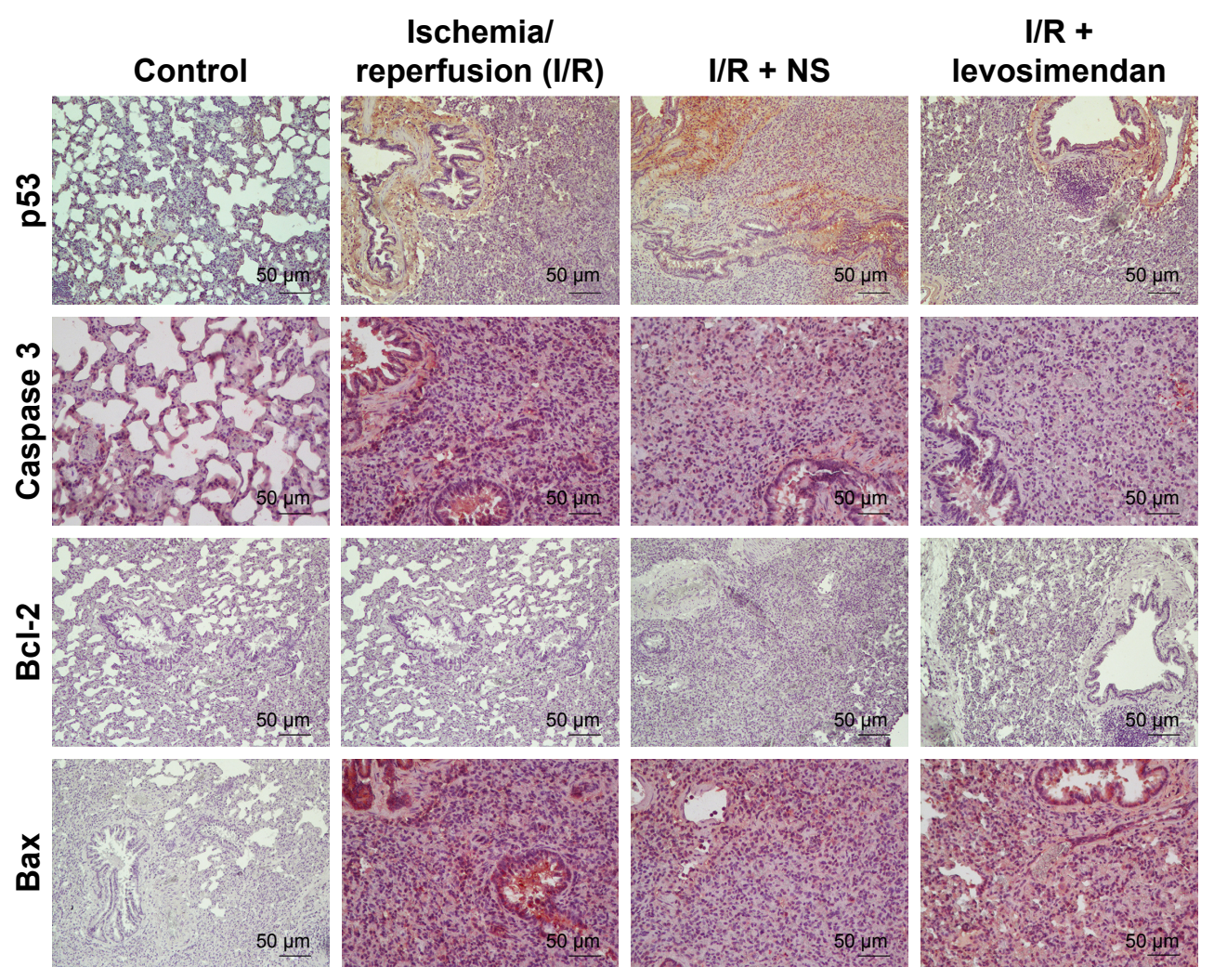

Figure I Lung tissue, p53, Bcl 2, Bax, and caspase 3 staining images of the C, I/R, IRTQ, and IRL groups. Abbreviations: C, control; IRL, IR-levosimendan; IRTQ, IR-thymoquinone; NS, Nigella sativa. 
TQ, the active constituent of NS seeds, has favorable effects with respect to oxidative stress and inflammation. In previous studies, pretreatment with TQ has been shown to have protective effects on lipid peroxidation process during $\mathrm{I} / \mathrm{R}$ injury in rat hippocampus and TQ also protects organs against oxidative damage. ${ }^{44}$ Furthermore, TQ may reduce oxidative stress through a direct antioxidant effect as well as through the induction of endogenous antioxidant enzymes. ${ }^{45}$

The hepatic I/R model has shown TQ to decrease hepatic tissue injury by decreasing reactive oxygen species formation and the activities of caspases 3,8 , and $9 .{ }^{46}$

Erkut et a $\mathrm{l}^{47}$ found caspase- 3 activity and its histologic damage of muscle tissues to be significantly high in the $\mathrm{I} / \mathrm{R}$ group. Caspase-3 activity and histopathologic injury were significantly low in the TQ and alpha-tocopherol $(\alpha-\mathrm{TP})$ groups. The antiapoptotic effect of the TQ plus $\alpha$-TP group was found to be higher. ${ }^{47}$

Our study compared expression of mediators of apoptosis such as $\mathrm{p} 53$, Bax, $\mathrm{Bcl} 2$, caspase-3, and histochemical changes of lung tissue after $\mathrm{L}$ and TQ pretreatment against distant organ I/R injury. Expression of p53 and Bax was more (4+) in the I/R group than in the IRTQ and IRL groups (2+, $3+)$. Caspase 3 expression was usually weak and diffuse (1+, $2+)$ in multiple areas, and Bcl 2 was not found to be expressed in any of the tissues. Immunohistochemical staining was more prominent in inflammatory areas and structures around the terminal bronchioles.

\section{Conclusion}

We believe that IRTQ and IRL groups also demonstrated the anti-apoptotic properties of TQ. TQ might be the probable protective mechanism protecting lung tissue in the myocardial I/R model in the rat. However, the clinical implications and appropriate pathophysiological mechanisms of the findings of the present study remain to be elucidated with further large-scale clinical studies.

\section{Disclosure}

The authors report no conflicts of interest in this work.

\section{References}

1. Lowenstein CJ. Myocardial reperfusion injury. $N$ Engl J Med. 2007; 357(23):2409-2410.

2. Meybohm P, Bein B, Brosteanu O, et al. A multicenter trial of remote ischemic preconditioning for heart surgery. N Engl J Med. 2015;373(15): 1397-1407.

3. Hausenloy DJ, Yellon DM. Targeting myocardial reperfusion injury - the search continues. $N$ Engl J Med. 2015;373(11):1073-1075.

4. Frank A, Bonney M, Bonney S, Weitzel L, Koeppen M, Eckle T. Myocardial ischemia reperfusion injury: from basic science to clinical bedside. Semin Cardiothorac Vasc Anesth. 2012;16(3):123-132.
5. Hausenloy DJ, Yellon DM. Myocardial ischemia-reperfusion injury: a neglected therapeutic target. J Clin Invest. 2013;123(1):92-100.

6. Gerczuk PZ, Kloner RA. An update on cardioprotection: a review of the latest adjunctive therapies to limit myocardial infarction size in clinical trials. J Am Coll Cardiol. 2012;59(11):969-978.

7. Eltzschig HK, Eckle T. Ischemia and reperfusion - from mechanism to translation. Nat Med. 2011;17(11):1391-1401.

8. Vilahur G, Juan-Babot O, Peña E, Oñate B, Casaní L, Badimon L. Molecular and cellular mechanisms involved in cardiac remodeling after acute myocardial infarction. J Mol Cell Cardiol. 2011;50:522-533.

9. Callender T, Woodward M, Roth G, et al. Heart failure care in lowand middle-income countries: a systematic review and meta-analysis. PLoS Med. 2014;11(8):e1001699.

10. Welbourn CR, Goldman G, Paterson IS, Valeri CR, Shepro D, Hechtman HB. Pathophysiology of ischaemia reperfusion injury: central role of the neutrophil. Br J Surg. 1991;78(6):651-655.

11. Lang XE, Wang X, Jin JH. Mechanisms of cardioprotection by isoflurane against I/R injury. Front Biosci (Landmark Ed). 2013;18:387-393.

12. Ansley DM, Wang B. Oxidative stress and myocardial injury in the diabetic heart. J Pathol. 2013;229(2):232-241.

13. Szocs K. Endothelial dysfunction and reactive oxygen species production in ischemia/reperfusion and nitrate tolerance. Gen Physiol Biophys. 2004;23(3):265-295.

14. Küçük A, Yucel M, Erkasap N, et al. The effects of PDE5 inhibitory drugs on renal ischemia/reperfusion injury in rats. Mol Biol Rep. 2012; 39(10):9775-9782.

15. Azarpira N, Kazemi K, Darai M. Influence of p53 (rs1625895) polymorphism in kidney transplant recipients. Saudi J Kidney Dis Transpl. 2014;25(6):1160-1165.

16. Singaravelu K, Devalaraja-Narashimha K, Lastovica B, Padanilam BJ. PERP, a $\mathrm{p} 53$ proapoptotic target, mediates apoptotic cell death in renal ischemia. Am J Physiol Renal Physiol. 2009;296(4):F847-F858.

17. Rognoni A, Lupi A, Lazzero M, Bongo AS, Rognoni G. Levosimendan: from basic science to clinical trials. Recent Pat Cardiovasc Drug Discov. 2011;6(1):9-15.

18. Toller WG, Stranz C. Levosimendan, a new inotropic and vasodilatory agent. Anesthesiology. 2006;104(3):556-569.

19. Erdei N, Papp Z, Pollesello P, Edes I, Bagi Z. The levosimendan metabolite OR-1986 elicits vasodilation by activating the K(ATP) and $\mathrm{BK}(\mathrm{Ca})$ channels in rat isolated arterioles. Br J Pharmacol. 2006;148(5): 696-702.

20. Katircioglu SF, Seren M, Parlar AI, et al. Levosimendan effect on spinal cord ischemia-reperfusion injury following aortic clamping. J Card Surg. 2008;23(1):44-48.

21. Yasa H, Yakut N, Emrecan B, et al. Protective effects of levosimendan and iloprost on lung injury induced by limb ischemia-reperfusion: a rabbit model. J Surg Res. 2008;147(1):138-142.

22. Yakut N, Yasa H, Bahriye Lafci B, et al. The influence of levosimendan and iloprost on renal ischemia-reperfusion: an experimental study. Interact Cardiovasc Thorac Surg. 2008;7(2):235-239.

23. Gali-Muhtasib H, Roessner A, Schneider-Stock R. Thymoquinone: a promising anti-cancer drug from natural sources. Int J Biochem Cell Biol. 2006;38(8):1249-1253.

24. El-Dakhakhny M. Studies on the chemical constitution of Egyptian $N$. sativa L. seeds. Planta Med. 1963;11(4):465-470.

25. Awad AS, Kamel R, Sherief MA. Effect of thymoquinone on hepatorenal dysfunction and alteration of CYP3A1 and spermidine/spermine $\mathrm{N}-1$-acetyl-transferase gene expression induced by renal ischaemiareperfusion in rats. J Pharm Pharmacol. 2011;63(8):1037-1042.

26. Farag MM, Ahmed GO, Shehata RR, Kazem AH. Thymoquinone improves the kidney and liver changes induced by chronic cyclosporine. A treatment and acute renal ischaemia/reperfusion in rats. $J$ Pharm Pharmacol. 2015;67(5):731-739.

27. Gökce EC, Kahveci R, Gökce A, et al. Neuroprotective effects of thymoquinone against spinal cord ischemia-reperfusion injury by attenuation of inflammation, oxidative stress, and apoptosis. J Neurosurg Spine. 2016;24(6):949-959. 
28. Gonca E, Kurt Ç. Cardioprotective effect of thymoquinone: a constituent of Nigella sativa L., against myocardial ischemia/reperfusion injury and ventricular arrhythmias in anaesthetized rats. Pak J Pharm Sci. 2015;28(4):1267-1273.

29. Hammad FT, Lubbad L. The effect of thymoquinone on the renal functions following ischemia-reperfusion injury in the rat. Int J Physiol Pathophysiol Pharmacol. 2016;8(4):152-159.

30. Sharma V, Bell RM, Yellon DM. Targeting reperfusion injury in acute myocardial infarction: a review of reperfusion injury pharmacotherapy. Expert Opin Pharmacother. 2012;13(8):1153-1175.

31. Gomez L, Paillard M, Thibault H, Derumeaux G, Ovize M. Inhibition of GSK3beta by postconditioning is required to prevent opening of the mitochondrial permeability transition pore during reperfusion. Circulation. 2008;117(21):2761-2768.

32. Nishihara M, Miura T, Miki T, et al. Erythropoietin affords additional cardioprotection to preconditioned hearts by enhanced phosphorylation of glycogen synthase kinase-3ß. Am J Physiol Heart Circ Physiol. 2006; 291(2):H748-H755.

33. Cannon RO 3rd. Mechanisms, management and future directions for reperfusion injury after acute myocardial infarction. Nat Clin Pract Cardiovasc Med. 2005;2(2):88-94.

34. Önem G, Saçar M, Aybek H, et al. Protective effects of cilostazol and levosimendan on lung injury induced by lower limb ischemiareperfusion. Turk J Thorac Cardiovasc Surg. 2012;20(3):577-583.

35. Kip G, Çelik A, Bilge M, et al. Dexmedetomidine protects from postmyocardial ischaemia reperfusion lung damage in diabetic rats. Libyan J Med. 2015;10(1):27828.

36. Malmberg M, Vähäsilta T, Saraste A, et al. Intracoronary levosimendan during ischemia prevents myocardial apoptosis. Front Physiol. 2012; 3:17.

37. Papp Z, Csapó K, Pollesello P, Haikala H, Edes I. Pharmacological mechanisms contributing to the clinical efficacy of levosimendan. Cardiovasc Drug Rev. 2005;23(1):71-98

38. Papp Z, Edes I, Fruhwald S, et al. Levosimendan: molecular mechanisms and clinical implications. Consensus of experts on the mechanisms of action of levosimendan. Int J Cardiol. 2012;159:82-87.
39. Katrancioglu N, Karahan O, Kilic AT, Altun A, Katrancioglu O, Polat ZA. The antiangiogenic effects of levosimendan in a CAM assay. Microvasc Res. 2012;83(3):263-266.

40. Grossini E, Caimmi PP, Platini F, et al. Modulation of programmed forms of cell death by intracoronary levosimendan during regional myocardial ischemia in anesthetized pigs. Cardiovasc Drugs Ther. 2010; 24(1):5-15.

41. Grossini E, Molinari C, Pollesello P, et al. Levosimendan protection against kidney ischemia/reperfusion injuries in anesthetized pigs. J Pharmacol Exp Ther. 2012;342(2):376-388.

42. Mansour MA. Protective effects of thymoquinone and desferrioxamine against hepatotoxicity of carbon tetrachloride in mice. Life Sci. 2000; 66(26):2583-2591.

43. Nagi MN, Mansour MA. Protective effect of thymoquinone against doxorubicin-induced cardiotoxicity in rats: a possible mechanism of protection. Pharmacol Res. 2000;41(3):283-289.

44. Hosseinzadeh H, Parvardeh S, Asl MN, Sadeghnia HR, Ziaee T. Effect of thymoquinone and Nigella sativa seeds oil on lipid peroxidation level during global cerebral ischemia-reperfusion injury in rat hippocampus. Phytomedicine. 2007;14(9):621-627.

45. Ismail M, Al-Naqeep G, Chan KW. Nigella sativa thymoquinone-rich fraction greatly improves plasma antioxidant capacity and expression of antioxidant genes in hypercholesterolemic rats. Free Radic Biol Med. 2010;48(5):664-672.

46. Abd El-Ghany RM, Sharaf NM, Kassem LA, Mahran LG, Heikal OA. Thymoquinone triggers anti-apoptotic signaling targeting death ligand and apoptotic regulators in a model of hepatic ischemia reperfusion injury. Drug Discov Ther. 2009;3(6):296-306.

47. Erkut A, Cure MC, Kalkan Y, et al. Protective effects of thymoquinone and alpha-tocopherol on the sciatic nerve and femoral muscle due to lower limb ischemia-reperfusion injury. Eur Rev Med Pharmacol Sci. 2016;20(6):1192-1202.
Drug Design, Development and Therapy

\section{Publish your work in this journal}

Drug Design, Development and Therapy is an international, peerreviewed open-access journal that spans the spectrum of drug design and development through to clinical applications. Clinical outcomes, patient safety, and programs for the development and effective, safe, and sustained use of medicines are the features of the journal, which

\section{Dovepress}

has also been accepted for indexing on PubMed Central. The manuscript management system is completely online and includes a very quick and fair peer-review system, which is all easy to use. Visit http://www.dovepress.com/testimonials.php to read real quotes from published authors. 